\title{
ETIKA BERDIALOG DAN METODOLOGI DEBAT DALAM AL-QUR'AN
}

\author{
Moh. Jufriyadi Sholeh \\ IDIA Prenduan Sumenep \\ Email: mohjufriyadisholeh̆gmail.com
}

\begin{abstract}
Absrak:
Melihat manusia sering melakukan pembantahan dalam hidupnya, maka al-Qur'an menjadikan debat sebagai salah satu pilar utama dari beberapa pilar dakwah, sebagaimana pula menjadikan debat sebagai bagian dari dialog. Istilah debat dan dialog digunakan oleh al-Qur' an dengan makna yang sama. Adapun metode perdebatan yang digunakannya, al-Qur'an menempuh berbagai macam metode yang dapat menyentuh sisi-sisi kejiwaan dari manusia, baik dari aspek logika, hati, perasaan dan inderanya. Dalam menyampaikan perdebatannya, al-Qur'an menggunakan susunan yang sangat kokoh, dalil-dalil yang sangat terang dan argumen-argumen yang sangat kuat dan dapat diterima oleh akal yang sehat, jiwa yang mulia dan hati yang suci. Debat yang qur'ani merupakan jalan dakwah kepada Allah dan dialog persuasive merupakan sunnah (ajaran) al-Qur'an yang harus dipegang erat oleh umat Islam dan harus diambil oleh mereka ketika berdebat dengan sesuatu yang lebih baik, dengan harapan lawan bicara mendapatkan petunjuk untuk kembali ke jalan yang benar. Langkahlangkah dialog dalam perdebatan tentunya harus tetap mematuhi etika dan ketentuan yang sudah ada.
\end{abstract}

Kata Kunci: al-Qur'an, jidal,hiwar

$$
\begin{aligned}
& \text { الملخص: } \\
& \text { ولما كان الإنسان أكثر جدلا في حياته يعتبر القرآن الجدال ركنا أساسيا من }
\end{aligned}
$$

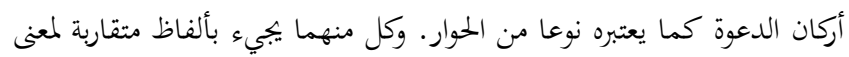

$$
\begin{aligned}
& \text { واحد فيه. ومنهج القرآن في الجدل يسلك طرائق مختلفة تخاطب الجوانب } \\
& \text { المختلفة في النفس الإنسانية، عقله وضميره ووجدانه وحواسه ويستخدم أحكم فئم }
\end{aligned}
$$

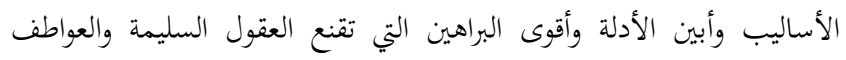

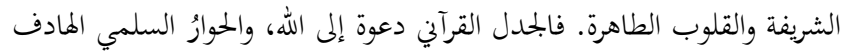




$$
\begin{aligned}
& \text { سنّة قرآنية ينبغي للمسلمين أن يتمسكوا بهاويأخذوا فيها بأسباب الإقناع }
\end{aligned}
$$

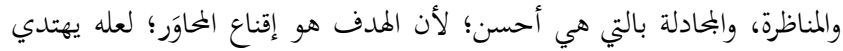

$$
\begin{aligned}
& \text { إلى الصواب وفق آداب وضوابط ينبغي مُراعاةًا. } \\
& \text { الكلمات الرئيسية: القرآن والجدال والحوار. }
\end{aligned}
$$

\section{Prolog}

Melihat kesombongan seringkali mendorong manusia untuk menebarkan benih-benih keraguan, mengacaukan fakta-fakta kebenaran dan menjadikan manusia keras kepala tidak mau menerima kebenaran yang sudah nyata, serta mendorong manusia menjadi pembantah yang nyata, maka al-Qur'an menjadikan debat sebagai salah satu dari tiga pilar aldakwah al-islamiyah.

Pada dasarnya debat bukanlah langkah pertama yang harus ditempuh oleh seorang da'i dalam berdakwah kepada Allah swt. Para ulama selalu menjahui perdebatan dalam bentuk apapun selama dua langkah pertama yaitu dengan hikmah dan mauidloh hasanah yang digariskan al-Qur'an masih efektif untuk dijadikan jalan utama meretas dakwah islamiyah.

Cara-cara dakwah dengan hikmah dan mauizah hasanah juga dijadikan langkah pertama para Nabi dalam menyampaikan amanah dari Allah kepada umatnya. Akan tetapi sifat pembantahan merupakan karakteristik yang tertanam dalam kepribadian manusia, sehingga pembawa kebenaran seringkali dihadapkan pada pembantahan yang akan mengantarkan mereka ke ranah perdebatan.

Untuk menjaga tujuan tercapainya dakwah Islam dalam menyebarkan kebenaran dan menghancurkan kebatilan, maka Al-Qur'an tidak hanya menjadikan debat sebagai langkah dakwah saja, tetapi Al-Qur'an juga mengajarkan etika-etika khusus dalam berdialog dan metode debat qur'ani dalam upaya mencari hasil yang positif dari setiap dialog dan perdebatan yang terjadi.

\section{Pengertian Debat (al-Jadal) dan Dialog (al-Hiwar)}

Kata "debat" dalam bahasa Arab berasal dari kata jadal, mujādalah,dan jidāl yang kesemuanya memiliki arti bahasa perbantahan yang sengit (al-ladad fí al-khusumah) ${ }^{1}$. Dalam al-Qur'an masalah debat terdapat dalam banyak ayat dan diungkapkan dengan berbagai bentuk kata (șighah al-kalimah), diantaranya berbentuk infinitive (masdar) seperti jidä ${ }^{2}$

1. Ibn Manzūur, Lisān al- 'Arab, juz 2, Kairo: Dār al-Hadith, 2003, 60-61

2 . lihatal-Qur'an surat al-Baqarah ayat 197; surat Hūd ayat 32. 
dan jadaP'. Ada pula yang diungkapkan dengan bentuk fi'il (kata kerja), baik fi'il mạdi, muḍariri' dan fi'il amr. ${ }^{4}$ Sedangkan kata"dialog" dalam bahasa Arabnya berasal dari kata muhāwarah dan hiwār yang artinya adalahjawāb 5 (menanggapi, menjawab, atau merespon).

Menurut istilah, debat (jadal) memiliki pengertian sebuah perundingan atau diskusi dengan saling sanggah atau adu argumen dengan upaya mengalahkan lawan. ${ }^{6}$ Adapaun kata dialog (hiwar) secara termenologi adalah percakapan antara dua orang atau antara beberapa pihak yang berseberangan pendapat, pikiran atau keyakinan. ${ }^{7}$

Dari pengertian debat (jadal) dan dialog (hiwar) di atas dapat dipahami bahwa kedua istilah atau termenologi tersebut memiliki makna dan penggunaan yang berbeda. Debat (jadal) digunakan untuk tujuan pembantahan dalam bentuk apapun; baik untuk memperkuat pendapat atau karena fanatisme buta yang tidak beralasan. Sedangkan arti dialog (hiwar) hanya digunakan atas sebuah percakapan antara dua belah pihak atau lebih dan tidak ada tujuan pembantahan.

Akan tetapi fakta di lapangan, istilah dialog(hiwar) tidak hanya memiliki pengertian sebagai percakapan semata, tetapi makna dialog jauh lebih luas penggunaannya dari artian yang ditunjukan oleh kata dialog sendiri. Dialog dalam realitas kehidupan adalah persaingan antara dua pihak dalam bentuk percakapan untuk saling menundukkan dengan teori pandang masing-masing, serta sikap saling menghormati dan dengan tujuan mencari solusi pemecahan masalah yang dihadapi. Akan tetapi, keabsenan etikaetika berdialog dalam sebuah percakapan akan membuahkan hasil yang negatif, sehingga solusi pemecahan yang dicari manjadi nihil.

Demikian pula istilah debat(jadal), dalam ajaran Islam bukanlah hanya sekadar perbantahan sengit yang menyia-nyiakan waktu dan jauh dari tujuan-tujuan positif; bukan hanya sebagai jalan mencari kemenangan belaka, akan tetapi debat merupakan salah satu metodologi dakwah untuk

${ }^{3}$. lihat al-Qur'an surat al-Kahf ayat 54; surat al-Zuhruf ayat 58 .

4. lihat al-Qur'an surat al-Nisā' ayat 107, 109; surat Hūd ayat 32, 74; surat Ghāfir ayat $4,5,13,35,56,69$; surat al-Hāj ayat 3, 8, 68;surat al-Nahl ayat 11, 125; surat al-Mujādalah ayat 1 , al-'Ankabūt ayat 46 , surat al-A'rāf ayat 71 , surat alKahf ayat 56, surat Luqmān ayat 20, surat al-An'àm ayat 25, 121; surat al-Ra'd ayat 13 , surat al-Shūrā ayat 35 ; surat al-Anfāl ayat 6 .

5. Ibn Manzūur, Lisān al- 'Arab, juz 2, 651

6. Mani' Abd. Halim Mahmūd dan Mohammad Amīn Abū Bakar Muawwad, Fath alRahmān fí Ulüm al-Qur'ān, 150.

${ }^{7}$.Ali Muhammad Șāleh Abdullah, Al-Hiwār al-Dīnī al-Ibrāhimī fì mīzān alQur'ān,Kairo: Dār al-Salām, 3007, 321-324. 
mendapatkan hasil positif dari perbantahan argumenasi yang disampaikan oleh masing-masing pihak yang berbeda pendapat. Akan tetapi hasil positif yang dicari dalam debat akan menjadi nihil juga apabila debat tersebut dibangun di luar etika-etika yang ditetapkan.

Dari fakta dan realitas di atas dapat disimpulkan, bahwa istilah debat (jadal) dan dialog (hiwar) walaupun memilki definisi tersendiri, akan tetapi praktek dan penggunaannya sering dipakai untuk maksud yang sama (yutlaqu ba' duha 'alā ba' ḍ). Bisa jadi antara debat dan dialog memiliki hubungan makna umum dan khusus. Artinya, dialog secara makna lebih umum dari debat, karena setiap perdebatan pasti ada dialog, yaitu percakapan dari kedua belah pihak atau lebih, dan dalam sebuah percakapan atau dialog belum tentu ada pembantahan dan pertentangan argumumentasi sebagaimana dalam debat.

\section{Urgensi Debat}

Konflik, pergulatan dan pertentangan antara kebaikan dan keburukan merupakan realitas yang akan selalu mewarnai titian hidup manusia mulai dari awal penciptaan sampai detik akhir umur dunia. Di mana ada manusia di sanalah konflik, pergulatan dan pertentangan akan terjadi. Adanya realitas ini tidak lain karena sifat pembantahan merupakan karakteristik yang tertanam dalam setiap individu manusia. Dengan karakteristik inilah manusia selalu ingin membantah, berdiskusi, berdialog mengenai segala hal yang dihadapinya.

Dalam al-Qur'an surat al-Kahf, ayat 54, Allah menegaskan bahwa manusia adalah makhluk yang paling banyak membantah. Sebagaimana juga ditegaskan dalam surat al-Nahl ayat 4 dan surat Yāsin, ayat 77, bahwa Allah telah menciptakan manusia dari mani, tiba-tiba ia menjadi pembantah yang nyata (khasim mubin). Kisah-kisah nyata tentang perbantahan manusia, terutama yang dilakukan oleh orang-orang Yahudi dan Nasrani juga telah dikisahkan oleh Allah dalam banyak ayat dalam al-Qur'an.

Sebagai kitab suci yang menjadi pegangan utama agama penutup, Islam, al-Qur'an telah menjadikan debat sebagai salah satu metode dakwah kepada Allah guna merespon, menjawab, dan menanggapi setiap bantahan yang datang dengan tujuan meluruskan keyakinan yang sesat dan pemahamanyang salah.

${ }^{8}$. Ibid, hal. 323-324, Barakat Muhammad Murād, Manhāj al-Jadal wa adab al-Hiwār fí al-Fikr al-Islämī, hal.17, Muhammad Sayyid Musayyar, al-Ilahiyāt fì al-Aqidah al-Islamiyah, Kairo: Maktab al-Īmān, t.th, 79. 
Allah berfirman : "Serulah (manusia) kepada jalan tuhanmu dengan hikmah dan pelajaran yang baik dan bantahlah mereka dengan cara yang baik." Menurut Syaikh Mutawalli Sha'rāwi, ayat ini menjelaskan konsep umum tentang langkah-langkah dakwah kepada Allah, ${ }^{10}$ dan debat merupakan salah satu langkah terpenting dalam berdakwah, khususnya ketika seorang da'i mendapatkan pembantahan dalam dakwahnya.

Bahkan debat dikategorikan oleh al-Qur'an sebagai bagian dari nasehat dalam agama, sebagaimana Allah sampaikan melalui lisan Nuh as. dalam surat Hūd ayat 32-34: "Mereka berkata: 'Hai Nuh, sesungguhnya kamu telah berbantah dengan kami, dan kamu telah memperpanjang bantahanmu terhadap kami, maka datangkanlah kepada kami azab yang kamu ancamkan kepada kami, jika kamu termasuk orang-orang yang benar." Nuh menjawab: "Hanyalah Allah yang akan mendatangkan azab itu kepadamu jika Dia menghendaki, dan kamu sekali-kali tidak dapat melepaskan diri." "Dan tidaklah bermanfaat kepadamu nasehatku jika aku hendak memberi nasehat kepada kamu, sekiranya Allah hendak menyesatkan kamu, Dia adalah Tuhanmu, dan kepada-Nya-lah kamu dikembalikan."

Dalam kisah al-Qur'an di atas, Nabi Nuh as. dituduh oleh umatnya telah banyak melakukan pembantahan terhadap mereka. Setiap dialog yang dilakukan olehnya dianggap oleh umatnya sebagai perdebatan yang telah memposisikan mereka sebagai pihak yang salah dan sesat, sehingga mereka menantang Nuh supaya mendatangkan azab bagi mereka untuk membuktikan bahwa ia benar-benar sebagai utusan. Menyikapi kemarahan umatnya, Nuh menyatakan bahwa yang dapat mendatangkan azab hanyalah Allah dan tidak akan ada seorang pun yang bisa lari dari azab tersebut apabila Dia telah berkehendak. Demikian pula tidak ada yang dapat memberikan petunjuk kepada seseorang apabila Dia hendak menyesatkan orang tersebut, termasuk nasehat-nasehat yang disampaikan Nuh yang dalam anggapan kaumnya nasehat-nasehat tersebut dianggap sebagai pembantahan atau perdebatan.

\section{Macam-macam Debat}

Berdasarkan ayat-ayat yang berbicara tentang perdebatan, para ulama membagi debat menjadi dua: 1) Debat Terpuji (jadal mamdūh), 2) Debat Tercela (jadal mazmūm).

\footnotetext{
${ }^{9}$ Al-Qur'an, al-Nahl:125.

10 Muhammad Mutawalli al-Sha'rāwì, Tafsìr al-Sha'rāwì, juz 13, t.tp: Maṭābi' Akhbār al-Yaum, t.th, 8282.
} 


\section{Debat Terpuji (jadal mamdūh)}

Perdebatan menjadi terpuji bahkan dianjurkan dalam Islam, apabila perdebatan tersebut didasari dengan niatan yang baik, dan dilakukan sesuai dengan kosep debat yang qur'āni, serta menggunakan etika-etika yang baik dalam proses diskusinya, sehingga hasil yang didapat dari perdebatan tersebut sesuatu yang positif yang tidak mencederai tujuan dakwah islamiyah. ${ }^{11}$ Debat yang semacam inilah yang dianjurkan al-Qur'an sebagaimana firman Allah dalam surat al-Nahl ayat 125: "Serulah (manusia) kepada jalan Tuhanmu dengan hikmah dan pelajaran yang baik dan bantahlah mereka dengan cara yang baik."

Menurut Sayyid Tanțāwi, perdebatan yang dianjurkan oleh al-Qur'an dalam ayat di atas adalah perdebatan yang didasarkan pada persuasi yang baik, kesopanan dan hati yang lapang karena sikap yang demikian lebih efektif dalam melunakkan hati para pembangkang dan menyadarkan mereka. Tidak ada perdebatan dalam Islam kecuali mencari atau menyampaikan kebenaran. ${ }^{12}$ Allah berfirman dalam surah al-'Ankabūt ayat 46 : "Dan janganlah kamu berdebat dengan ahli kitab, melainkan dengan cara yang paling baik, kecuali dengan orang-orang zalim di antara mereka.”

\section{Debat Tercela (jadal mazmūm)}

Menurut Abū Umāmah al-Shīil, sebuah perdebatan menjadi tidak baik dan tercela ketika perdebatan tersebut tidak didasari oleh niat yang baik, seperti debat dengan tujuan mencari popularitas, kemenangan, pamer keilmuan atau debat tersebut tidak didasari ilmu pengetahuan. ${ }^{13}$ Debat yang didasari niat dan tujuan-tujuan yang tidak baik tentunya hanya akan menguras tenaga dan menyia-nyiakan waktu, karena debat tersebut tidak akan menghasilkan sesuatu yang positif dari kedua belah pihak yang berselisih pendapat. Perdebatan tersebut hanya akan mendorong pihak-pihak yang berseberangan argumen untuk saling menyudutkan dan memancing emosi lawan guna mencari kemenangan, bukan kebenaran. Kedua belah pihak tidak akan objektif dalam berhujjah, sehingga kebenaran menjadi kabur dan kebatilan dipoles menjadi tanpak sebagai sesuatu yang hak.

11. Ali Muhammad Șāleh Abdullah, Al-Hiwār al-Dīnī al-Ibrāhīmī fí mīzān alQur'ān,19-21; Mani' Abd. Halim Mahmūd dan Mohammad Amin Abū Bakar Muawwad, Fath al-rahmān fì Ulüm al-Qur'ān, 150-153.

12. Muhammad Sayyid Ṭantāwīi, Al-Tafsìr al-Wasìt, juz 8, Kairo: Dār Nahḍah Miṣr, t.th, 262

13. Abu Umāmah Nawwār bin Al-Shīlí, Al-Aql Al-Fiqhī Ma'àlim Wa Dawābit, Kairo: Dār al-Salām, 2008 M-1429 H, 151. 
Dalam beberapa ayatnya, al-Qur'an menjelaskan beberapa bentuk perdebatan yang tercela, seperti dalam surat al-Kahf, ayat 56 diterangkan bahwa orang-orang yang kafir membantah dengan yang batil agar dengan demikian mereka dapat melenyapkan yang hak. Menurut Abdurrahmān alDamashqi, ayat 56 dari surat al-Kahf ini menjelaskan bahwa pernyataan orang-orang kafir dalam perdebatannya tidak memiliki pijakan yang nyata dan yang ada hanya kebatilan. ${ }^{14}$ Mereka berdebat tanpa dasar ilmu pengetahuan, tanpa petunjuk dan tanpa kitab (wahyu) yang bercahaya. ${ }^{15}$

\section{Faktor-faktor penyebab adanya jadal (perdebatan) atau hiwār (dialog)}

Perdebatan atau dialog merupakan salah satu solusi penyelesaian masalah yang debatabel yang disikapi oleh satu pihak dengan sikap yang berbeda dengan pihak lain. Dengan perbedaan tersebut timbullah pembelaan atas sikap masing-masing dengan argumen-argumen dan bukti-bukti yang akan memperkuat sikapnya. Adanya perbedaan sikap, pandangan dan pendapat tidak lain karena faktor-faktor di bawah ini:

\section{Pertama, Perbedaan merupakan sunnatullah}

Di antara kekuasaan dan kebesaran Allah swt. Adalah penciptaan manusia dan perbedaan-perbedaan dalam diri manusia itu sendiri. Baik perbedaan budaya, tradisi, warna kulit, bahasa, cara berfikir dan perbedaan berpendapat dalam menyikapi masalah yang dihadapi.

Selain menjadi salah satu bukti keagungan dan kebesaran Allah swt, perbedaan juga ditetapkan sebagai sunnah-Nya (hukum alam)yang akan terus mewarnai kehidupan manusia. Hal ini Allah tegaskan dalam firmanNya: "Jikalau Tuhanmu menghendaki, tentu Dia menjadikan manusia umat yang satu, tetapi mereka senantiasa berselisih pendapat. Kecuali orangorang yang diberi rahmat oleh Tuhanmu. Dan untuk itulah Allah menciptakan mereka." Menurut Țāhir bin 'Āshūr, perbedaan akan selalu ada di antara manusia karena hal tersebut bagian dari tuntutan diciptakannya akal pikiran. ${ }^{17}$

14 . Abdurrahmān bin Hasan al-Damashqīi, Al-Haḍārah al-Islāmiyah Asāsuhā wa Wasā'iluhā, Damaskus: Dār al-Qalam, 1418, 38

${ }^{15}$. Lihat al-Qur'an surat al-Hājj ayat 3.

${ }^{16} \mathrm{Al}$-Qur'an, surat Hūd ayat 118-119.

${ }^{17}$ Muhammad al-Ṭāhir bin Āshūr, al-Tahrīr wa al-Tanwīr, juz 12, Tunis: al-Dār alTünisiyah li al-Nashr, 1984, 189. 
Etika Berdialog Dan Metodologi Debat dalam Al-Qur'an

\section{Kedua, Ketidaksamaan daya tangkap atau kecerdasan (ikhtilāf al- madārik)}

Tingkat kecerdasan manusia antara yang satu dengan yang lain diciptakan oleh Allah dengan tingkatan yang berbeda-beda. Ada di antara mereka yang tergolong tingkat kecerdasannya tinggi, ada yang sedang dan ada yang sangat rendah sekali. Tingkat kecerdasan atau daya tangkap seseorang sangat besar pengaruhnya terhadap pemahaman, pandangan atau sikap yang diambil atas suatu masalah. Dengan gaya pandang yang berangkat dari perbedaan daya tangkap, maka tidak diragukan lagi akan adanya perbedaan-perbedaan yang akan menjadi benih timbulnya perdebatan. Dalam al-Qur'an Allah menegaskan adanya ketidaksamaan orang-orang yang mengetahui dengan orang-orang yang tidak mengetahui dan hanya orang yang berakallah yang dapat menerima pelajaran. ${ }^{18}$

Menurut Ibnu Ashür, yang dimaksud dengan orang-orang berakal dalam firman Allah tersebut adalah orang-orang yang berilmu. Ilmu dan akal merupakan kata yang sinonim (murādif), sehingga maksud dari ayat ini adalah: tidak sama orang-orang yang memiliki ilmu karena mereka mengetahui hakekat sesuatu sesuai dengan hahekatnya dan amal perbuatan mereka akan sesuai dengan keilmuannya, sedangkan orang-orang yang tidak berilmu maka tidak mengetahui sesuatu sesuai dengan hakekatnya, bahkan hakekat dari sesuatu tersebut akan tidak jelas baginya dan amal perbuatannya akan menjadi kacau, seperti halnya orang-orang yang menganggap batu sebagai Tuhan dan menjadikan kekufuran sebagai bentuk syukur. ${ }^{19}$

\section{Ketiga, perbedaan orientasi dan kecenderungan}

Setiap individu atau kelompok (mazhab) manusia memilki latar belakang kehidupan yang berbeda; baik latar belakang keluarga, pendidikan, lingkungan, budaya dan semacamnya. Latar belakang kehidupan yang melingkupi mereka ini tentunya sangat dominan sekali dalam pembentukan karakteristik kepribadian yang akan mempengaruhi arah orentasi dan kecenderungan langkah yang akan dituju.

Orang yang berlatar belakang pendidikan bahasa dan sastra akan memiliki ittijah (kecenderungan) berfikir yang berbeda dengan orang yang berlatar belakang pendidikan syariah. Para ahli hadis akan memiliki kecenderungan pandangan yang tidak sama dengan ulama kalam dalam sebuah pemahaman atau penafsiran.

18. Al-Qur'an surat Al-Zumar ayat 9.

19 . Muhammad al-Ṭāhir bin Âshūr, al-Tahrïr wa al-Tanwïr, juz 23, hal. 349 
Etika Berdialog Dan Metodologi Debat dalam Al-Qur'an

\section{Keempat, Fanatisme}

Fanatisme merupakan benalu penghambat kemajuan dan penyakit yang melemahkan nalar kritis. Fanatismetelah menjadikan seseorang buta akan kebenaran, ia tidak akan objektif dalam menyikapi sesuatu. Apapun yang datang dari pendahulu, atau yang didoktrinkan oleh golongannya akan diterima dengan tanpa nalar kritis. Ia merasa apa yang ada dalam golongannya sebagai kebenaran mutlak. Ia akan memandang orang yang di luar kelompoknya dengan pandangan sebelah mata.

Realita ini telah banyak diungkap oleh al-Qur'an, dimana orang-orang musyrik dengan kokohnya tetap berpegang teguh kepada ajaran-ajaran pendahulunya, walaupun ajaran-ajaran tersebut sangatlah jauh dari kebenaran. Allah berfiman: "Dan apabila dikatakan kepada mereka: ikutilah apa yang telah diturunkan Allah. Mereka menjawab: Tidak, tetapi kami hanya mengikuti apa yang telah kami dapati dari nenek moyang kami, Walaupun nenek moyang mereka itu tidak mengetahui suatu apapun, dan tidak mendapat petunjuk?'20

Fenomena fanatisme tidak hanya terjadi di tengah orang-orang musyrik, tetapi juga dijumpai di tengah masyarakat muslim. Tidak sedikit pengikut atau pedukung sebuah madzhab dalam Islam yang dililit oleh benalu fanatisme, sehingga mereka memandang madzhabnya sebagai kebenaran mutlak yang jauh dari kesalahan. Akibatnya, perbedaan dalam madzhab Islam yang seharusnya menjadi rahmah berubah menjadi niqmah (bencana). Dengan fanatismenya, mereka memvonis pihak lain sebagai pihak yang salah, bahkan dianggap keluar dari agama Islam.

\section{Kelima, Sulitnya topik pembahasan (ghumud al-maudū')}

Rumitnya masalah yang menjadi topik dan pokok pembahasan dalam sebuah diskusi atau kajian akan memeras otak untuk bisa memecahkannya. Apalagi untuk membuat kesepahaman dengan orang lain, sekadar untuk pemahaman diri saja sangatlah susah. Maka tidaklah heran kalau perbedaan akan timbul dalam pemahaman tersebut. Masing-masing pihak akan menyampaikan pendapatnya sesuai dengan hasil pemahamannya sendiri.

\section{Etika Berdialog dalam Al-Qur'an}

Perbedaan pendapat, penafsiran, dan pandangan dalam menyikapi suatu masalah merupakan bagian dari fenomena kehidupan yang akan selalu menghiasi keberlangsungan hidup bermasyarakat. Aneka ragam pendapat dalam menyikapi sebuah terma adalah hal yang wajar. Bahkan di balik

20. Al-Qur'an surat al-Baqarah ayat 170. 
keanekaragaman pandangan dan pendapat bisa memberikan pemahaman yang lebih valid terhadap masalah yang diperselisihkan. Hal ini bisa terjadi apabila sudut pandang dari masing-masing pihak sama-sama ditegaskan dengan alasan-alasannya, sehingga yang dihasilkan dari penegasan alasanalasan tersebut menghapus kedebatebelan terma atau setidaknya perbedaan yang ada hanyalah perbedaan variasi pandangan (ikhtiläf tanawwu') bukan perbedaan yang bersifat kontradiksi (ikhtiläf tanāqud).

Untuk bisa mendapatkan hasil yang baik yang bisa diterima oleh kedua pihak yang berseberangan pendapat, maka dibutuhkan adanya kesepahaman, kearifan dan kelapangan dada dari keduanya. Kedua belah pihak harus membangun dialog atau perdebatannya berdasarkan etika-etika al-Quran. Secara eksplisit al-Qur'an tidak menjelaskan dengan rinci etikaetika tersebut, tetapi secara inplisit etika-etika tersebut telah disampaikan oleh al-Qur' an dalam banyak ayatnya. Di antara etika-etika tersebut adalah:

\section{Pertama, menetapi kejujuran dan menjauhi kelicikan ${ }^{21}$}

Jujur merupakan modal utama untuk menyelesaikan sesuatu yang diperdebatkan. Tanpa sifat jujur sebuah masalah bisa berbalik dari fakta yang sebenarnya. Dalam berdialog atau berdebat, kedua belah pihak yang berseberangan pendapat harus berpegang teguh dengan aturan ini. Tidak memutar balikkan fakta, tidak membuat-buat dalil palsu, tidak curang dengan menyodorkan bukti-bukti palsu dan sebagainya.

Allah swt. berfirman: "Hai orang-orang yang beriman, bertakwalah kepada Allah, dan hendaklah kamu bersama orang-orang yang benar (jujur). ${ }^{92}$ Ayat ini memerintahkan orang-orang yang beriman untuk selalu bersama-sama orang-orang yang benar dalam memeluk agama Allah; baik dalam niatnya, perkataan, perbuatan dan keikhlasannya, karena sesunggunya tidak ada kebenaran (kejujuran) dalam sesuatu, kecuali akan mempercantik sesuatau tersebut, dan sebaliknya tidak ada kebohongan dalam sesuatu, kecuali akan memperburuk sesuatu tersebut. ${ }^{23}$

Menurut Imam al-Qurțūbì, sudah menjadi kewajiban bagi setiap orang yang paham dan mengerti tentang Allah untuk selalu menetapi kejujuran dalam perkataannya, ikhlas dalam beramal, dan suci dalam tingkah lakunya. Barang siapa yang menetapi hal tersebut maka akan bertemu (bersama) al-

${ }^{21}$. Muhammad Sayyid Ṭanțāwì, Adab al-Hiwār fỉ al-Islām, t.tp: Majma' Mațābi’ alAzhar, t.th, 16

22. Al-Qur'an surat al-Taubah ayat 119 .

23. Muhammad Sayyid Țantāāì, al-Tafsìr al-Wasịt li al-Qur'ān al-Karīm,juz 6, Kairo: Dār al-Nahụah, cet. I,hal. 424 
abrär (orang-orang yang berbakti) dan bisa mencapai ridla Dzat Yang Maha Pengampun. ${ }^{24}$

Dalam sabdanya, Nabi Muhammad saw. menjelaskan arti sebuah kejujuran. Kejujuran merupakan energi positif yang akan mendorong seseorang untuk selalu berada dalam jalur kebaikan, dan sebaliknya kedustaan merupakan energi negatif yang akan mendorong seseorang menuju kejelekan. ${ }^{25}$

Dalam Al-Qur'an telah dikisahkan tentang kejujuran para utusan Allah ketika berdialog dengan umatnya, seperti kisah nabi Musa ketika berdialog dengan Fir'aun. Dalam kisahnya Nabi Musa datang menemui Fir'aun untuk menyampaikan ajaran Allah, maka Fir'aun berusaha untuk membungkam Nabi Musa agar tidak menyampaikan ajaran Allah kepadanya dengan cara menyebut jasa-jasanya atas Musa dan mengingat-ngingat kesalahan yang dilakukan Musa di masa lalu. Menanggapi semua pernyataan Fir'aun, Musa dengan jujur mengakui apa yang telah terjadi sebelumnya termasuk kesalahan yang telah ia perbuat kepada orang Qibți. Ia tidak mengingkari semua yang telah terjadi, tetapi ia juga memberikan alasanalasannya. ${ }^{26}$

\section{Kedua, menentukan tema dialog yang akan didiskusikan (Tahdid al- Maudū', $)^{27}$}

Demi tercapainya tujuan baik dalam diskusi dan supaya diskusi tersebut tidak menyia-nyiakan waktu akibat ketidakjelasan permasalahan yang diperbincangkan, maka sebelum memulai diskusi kedua belah pihak bersepakat atas tema yang akan didiskusikan. Dalam al-Qur'an, Allah mengajarkan Nabi Muhammad agar mengajak Ahli Kitab berpegang kepada satu kalimat yang tidak ada perselisihan antara Nabi dengan mereka. ${ }^{28}$ Petunjuk Allah kepada Nabi Muhammad ini mengajak ahli kitab menentukan tema dialog antara mereka dengan orang-orang muslim, serta

24. Abū Abdillah al-Qurtūīìi, al-Jāmi' li Ahkām al-Qur'ān, juz 8, Kairo: Dār alKutub al-Mișrîyah, 1964, 289.

25. Muhammad bin Ismail al-Bukhārī, Sahīh al-Bukhārī, juz 5 ditahqiq Mustafāā Diyab al-Biwa, Bairut: Dar Ibn Katsir, 1987, 2261; Muslim bin Hujjaj al-Qusyairi, Sahīh Muslim, juz 4, ditahqiq Muhammad Fu'ad Abd Baqi, Bairut: Dār Ihyā' alTurāth al-'Arabi, t.th, 2012.

${ }^{26}$. lihat al-Qur'an surat al-Syu' arā, ayat 10-22

27. Ali Muhammad Sāleh Abdullah, al-Hiwār al-Dīnī al-Ibrāhimī fỉ Mizān al-Qur'ān, 337; Abū Umāmah Nawwār bin al-Shāli, al-Aql al-Fiqhỉ Ma'ālim wa Dawābit,, hal 150.

${ }^{28}$. Lihat al-Qur'an, surat Ali Imran, ayat 64 
menjelaskan permasalahan yang terjadi di antara mereka hanya satu yaitu posisi mereka yang sama-sama sebagai pemeluk agama langit.

\section{Ketiga, saling memberi kesempatan berargumenasi ${ }^{29}$}

Dalam berdiskusi, masing-masing pihak tidak boleh berbicara berbarengan. Semua pihak harus saling memberi kesempatan untuk menyampaikan pendapatnya masing-masing. Tidak saling memotong pembicaraan. Runcingnya perbedaan dan besarnya permusuhan jangan sampai menampakkan sifat egois dan acuh tak acuh dalam mendengarkan argumenasi orang lain. Jangan sampai merasa dirinya benar sendiri.

Dalam dialog antara Allah dengan Iblis, Allah Sang Penguasa Mutlak jagad raya Yang Maha Kuasa atas segala sesuatu tetap memberikan peluang kepada Iblis untuk menyampaikan alasan-alasan pembangkangannya. Kenapa ia enggan ikut bersama-sama malaikat bersujud kepada Adam sesuai perintah-Nya. Alasan-alasannya ia utarakan kepada-Nya dan Dia tidak membaikot Iblis untuk berargumen sehingga dialog tetap berjalan. ${ }^{30}$

\section{Keempat, menetapi pokok pembahasan (iltizām al-madū'iyah) ${ }^{31}$}

Maksud dari etika ini adalah masing-masing pihak yang berdialog atau yang berdiskusi tetap mengkonsentrasikan pembicaraannya pada masalah yang diperselisihkan, tidak ngelantur ke mana-mana (ngalor-ngidul: jawa), sehingga masalah tersebut tidak bertambah rumit dan waktu tidak tersia-siakan oleh kerumitan tersebut.

Para utusan Allah sangat memperhatikan etika ini dalam berdialog dengan umatnya. Mereka menanggapi setiap tuduhan atau bantahan kaumnya dengan tanggapan dan jawaban yang sesuai dengan masalahmasalah yang dilontarkan mereka, seperti yang dilakukan oleh Nabi Nuh as. ketika menjawab tuduhan pemuka-pemuka kaumnya yang menuduhnya sebagai orang yang sesat. Mereka berkata: "Sesungguhnya kami memandang kamu dalam kesesatan yang nyata. ${ }^{\prime 32}$

Menanggapi tuduhan tersebut, Nabi Nuh langsung menjawab dengan jawaban yang tegas atas tuduhan tersebut dengan berkata: "Hai kaumku, tidak ada padaku kesesatan sedikitpun tetapi aku adalah utusan Tuhan semesta alam." "Aku sampaikan kepadamu amanat-amanat Tuhanku dan aku memberi nasehat kepadamu, dan aku mengetahui dari Allah apa yang

29. ibid, hal 336; Abū Umāmah Nawwār bin al-ShāTi, al-Aql al-Fiqhī Ma'ālim wa Dawābit, hal 150.

${ }^{30}$. Lihat al-Qur'an surat al-Hijr ayat 30-33

31. Muhammad Sayyid Ṭanțāwì, Adab al-Hiwār fì al-Islām, hal. 23

${ }^{32}$. Al-Qur' an surat al-A'räa ayat 60 
Etika Berdialog Dan Metodologi Debat dalam Al-Qur'an

tidak kamu ketahui. ${ }^{33}$ Dalam tanggapannya ini, Nabi Nuh tidak menanggapi dengan jawaban yang penuh emosi, tetapi ia menanggapi dengan tenang dan tidak keluar dari permasalan yang ada.

Kelima, menggunakan hujjah yang kuat, tegas, logis dan menunjukkan bukti-bukti yang akurat. ${ }^{34}$

Kuatnya hujjah, tegasnya sebuah argumen, logisnya alasan dan akuratnya sebuah bukti tidak hanya akan meng-clearkan persoalan, akan tetapi juga akan memadamkan bara ketakaburan lawan, mematikan nyali musuh dan menundukkan kebathilan pada kebenaran. Nabi Ibrahim as. salah satu contoh yang dikisahkan Allah dalam al-Qur'an, telah menjadikan raja yang mendebatinya dengan dasar kesombongan dan kecongkakan harus bungkam di depan hujjah-hujjah-nya yang kuat dan raja tersebut diam seribu kata dengan keheranan.

Dalam al-Qur'an Allah mengisahkan kejadian tersebut dengan berfirman: "Apakah kamu tidak memperhatikan orang yang mendebati Ibrahim tentang Tuhannya (Allah) karena Allah telah memberikan kepada orang itu pemerintahan (kekuasaan). Ketika Ibrahim mengatakan: 'Tuhanku ialah yang menghidupkan dan mematikan,' orang itu berkata: 'Saya dapat menghidupkan dan mematikan.' Ibrahim berkata: 'sesungguhnya Allah menerbitkan matahari dari timur, maka terbitkanlah dia dari barat,' lalu heran terdiamlah orang kafir itu; dan Allah tidak memberi petunjuk kepada orang-orang yang dzalim. ${ }^{35}$

Maksud dari perkataan raja tersebut -“Saya dapat menghidupkan”bukan berarti ia bisa memberi nyawa kepada orang yang mati untuk hidup kembali, tapi yang dimaksud adalah ia punya kuasa memberikan ampunan (amnesti) kepada orang-orang yang ia kehendaki untuk dibunuh, sehingga orang tersebut bisa menghirup udara kehidupan. Adapun maksud dengan kata - "mematikan"- ialah membunuhnya; dan perkataan-perkataan ini hanya untuk mengejek Nabi Ibrahim as.

Dalam menghadapi hujjah-hujjah raja tersebut sebenarnya Nabi Ibrahim bisa mematahkannya dengan berkata: "Sesungguhnya pernyataanmu tentang bisa menghidupkan dan mematikan bukanlah persoalan yang sesungguhnya, akan tetapi apa yang kamu lakukan adalah kediktatoran dan penganiayaan." akan tetapi Nabi Ibrahim tidak

33. Ibid, ayat 61-62

34. Ali Muhammad Șāleh Abdullah, al-Hiwār al-Dīnì al-Ibrāhimī fì mīzān al-Qur'ān, 334.

35 . Al-Qur'an surat al-Baqarah ayat 258 
menggunakan hujjah ini, ia malah membawa perhatian musuh ke persoalan lain yang masih satu topik pembahasan -yaitu tentang kekuasaan Allah yang akan mengantarkannya ke argumen-argumen yang lebih kuat dan nyata; lalu ia berkata: "Sesungguhnya Allah menerbitkan matahari dari timur, maka terbitkanlah dia dari barat." Dengan hujjah inilah akhirnya raja yang mendebatinya hanya tercengang keheranan dan diam seribu kata.

\section{Keenam, rendah hati (tawadu') dan menjauhi sifat-sifat sombong ${ }^{36}$}

Rendah hati merupakan salah satu sifat yang terpuji, karena dengan sifat inilah seseorang bisa berjiwa besar untuk menghargai orang lain. Beda halnya dengan sifat sombong, sifat ini telah menjadikan pemiliknya keras kepala, tidak mau menerima kebesaran orang lain dan tidak objektif dalam menyikapi sesuatu. Dalam sabdanya Nabi menegaskan bahawa kesombongan itu menolak kebenaran dan meremehkan orang lain. ${ }^{37}$

Sebuah dialog, diskusi dan perdebatan akan bisa berbuah kebaikan apabila dibangun di atas dasar keikhlasan dan kerendahan hati yang steril dari bakteri-bakteri kesombongan. Sebaliknya apabila kesombongan telah menggerogoti sebuah perdebatan, maka jangan berharap bisa membuahkan kesepakatan atau kesepahaman yang positif.

Salah satu kisah tauladan yang diangkat oleh al-Qur'an berkenaan dengan etika ini adalah kisah Nabi Syu'aib ketika menghadapi kaumnya yang telah banyak melakukan penyimpangan-penyimpangan, serta mengejeknya. Ia tetap bertutur kata yang sopan, ramah dan lemah lembut yang terangkai dari kerendahan hati. Ia berkata: 'Hai kaumku, bagaimana pikiranmu jika aku mempunyai bukti yang nyata dari Tuhanku dan dianugerahi-Nya aku dari pada-Nya rezki yang baik (patutkah aku menyalahi perintah-Nya? Dan aku tidak berkehendak menyalahi kamu (dengan mengerjakan) apa yang aku larang. Aku tidak bermaksud kecuali (mendatangkan) perbaikan selama aku masih berkesanggupan. Dan tidak ada taufik bagiku melainkan dengan (pertolongan) Allah. Hanya kepada Allah aku bertawakkal dan hanya kepada-Nya-lah aku kembali. ${ }^{38}$

\footnotetext{
36 . Ali Muhammad Șāleh Abdullah, al-Hiwār al-Dīnī al-Ibrāhimī fì mīzān al-Qur'ān, 335.

37 . Muslim bin Hujjāj al-Qushairī, Shahih Muslim, juz 1 ditahqiq Muhammad Fu'ad Abd Baqi, 93

38 . Al-Qur' an surat Hūd ayat 88 .
} 


\section{Ketujuh, menghargai pendapat orang lain ${ }^{39}$}

Sebesar apapun perbedaan yang terjadi, apabila tidak ada kesepakatan dari masing-masing-masing pihak atas masalah yang diperdebatkan, maka masing-masing pihak harus tetap menghargai pendapat dari lawannya. Tidak ada yang ngotot memaksakan pendapatnya kepada pihak lain. Biarlah masing-masing pihak berpegang teguh pada prinsip dan pandanganpandangannya sendiri.

Etika ini sesuai dengan petunjuk al-Qur'an surat al-Kāfirūn yang memberikan kebebasan untuk mengamalkan konsep kehidupan sesuai dengan keyakinan masing-masing. Semua pihak boleh mengamalkan agamanya atau pendapatnya masing-masing, tetapi tidak boleh memaksakan agamanya atau pendapatnya kepada orang lain. Untukmulah agamamu dan untukkulah agamaku. ${ }^{40}$

\section{Kedelapan, kembali ke jalan yang benar apabila telah nyata kebenaran} tersebut. $^{41}$

Perbedaan bukanlah hal yang tercela, tapi yang tercela adalah berlarut-larut dalam kesalahan dan kesesatan serta tidak mau kembali ke jalan yang benar yang sudah tampak jelas kebenarannya. Para malaikat menjadi tetap terpuji di hadapan Allah karena mereka tidak memperpanjang sanggahannya kepada Allah setelah kebenaran tampak terang di hadapannya. Mereka langsung mengakui kebenaran Allah dan mengakui kelemahan hujjah-hujjah-nya seraya berkata: "Maha Suci Engkau, tidak ada yang kami ketahui selain dari apa yang telah Engkau ajarkan kepada kami; sesungguhnya Engkau-lah yang Maha Mengetahui lagi Maha Bijaksana. "\$2

Sebelumnya mereka menyanggah kebijakan Allah yang telah menjadikan Adam sebagai khalifah di bumi seraya berkata, "Mengapa Engkau hendak menjadikan (khalifah) di bumi itu orang yang akan membuat kerusakan padanya dan menumpahkan darah, padahal kami senantiasa bertasbih dengan memuji Engkau dan menyucikan Engkau?" Tuhan berfirman, "Sesungguhnya aku mengetahui apa yang tidak kamu ketahui." Dan Dia mengajarkan kepada Adam nama-nama (benda-benda) seluruhnya, kemudian mengemukakannya kepada para malaikat, lalu berfirman,

\footnotetext{
39 . Ali Muhammad Șāleh Abdullah, al-Hiwār al-Dīnì al-Ibrāhimī fì mīzān al-Qur'ān, 337.

40. Lihat al-Qur'an surat al-Kāfirūn ayat 1-6

${ }^{41}$. Ali Muhammad Șāleh Abdullah, al-Hiwār al-Dīnī al-Ibrāhimī fì mīzān al-Qur'ān, 339.

42. Lihat al-Qur'an surat al-Baqarah ayat 32
} 
"Sebutkanlah kepada-Ku nama benda-benda itu jika kamu memang orangorang yang benar!"

\section{Potret perdebatan dan tema-tema dialog dalam al-Qur'an}

Ada banyak kisah perdebatan dan dialog yang diangkat al-Qur'an sebagai ibrah bagi umat manusia. Di antara kisah-kisah dialog yang diangkat oleh al-Qur'an adalah dialog yang terjadi antara Allah dengan makhluq-Nya, baik dengan para utusan-Nya, para malaikat-Nya dan dengan Iblis yang terlaknat. Ada juga perdebatan atau dialog antara para rasul dan umatnya. Adapula dialog-dialog antara orang-orang mukmin dengan orang-orang munafik dan dialog-dialog lainnya.

Dari beberapa kisah tentang dialog yang diangkatnya, al-Qur'an juga mengangkat banyak tema dalam kisah-kisah tersebut, seperti tema tentang akidah, sosial, keadilan, kejujuran dan lain-lain. Dari sekian tema yang ada, Tema akidah merupakan tema yang banyak diangkat oleh al-Qur'an dengan bentuk dialog atau perdebatan. Diangkatnya tema ini dengan bentuk dialog atau perdebatan tidak lain karena masalah ini adalah masalah ghaib yang rawan dengan bantahan dan pengingkaran, serta posisinya yang menjadi pondasi utama dalam agama. Semua amal kebajikan yang tidak dibangun di atas pondasi ini akan menjadi sia-sia atau tidak diterima oleh Allah. Oleh karenanya tidak heran kalau al-Qur'an sebagai kitab petunjuk Ilahi banyak mengangkat tema akidah dalam bentuk perdebatan. ${ }^{44}$

Dalam menanamkan dasar-dasar keyakinan (akidah) dan memantapkan nilai keimanan kepada Allah, malaikat, kitab suci, para rasul dan kepercayaan akan adanya hari akhir, al-Qur'an memberikan beberapa argumen yang kuat, tegas, lugas dan logis yang diperkuat dengan ayat-ayat penciptaan. Dengan ungkapan yang mudah, singkat, padat dan jelas, kebenaran hujjah al-Qur'an dapat diterima oleh nurani semua insan. Faktafakta nyata yang ditunjukkan al-Qur'an tidak bisa dibantah oleh siapapun.

\section{Metodologi Debat dalam al-Qur'an}

Dalam berdebat dengan para penantangnya, al-Qur'an banyak menggunakan dalil dan bukti-bukti kuat dan jelas yang dapat dimengerti masyarakat awam dan kaum intelek. Al-Qur'an membatalkan setiap kerancuan yang meresahkan dan mematahkannya dengan menggunakan ungkapan-ungkapan yang terang dan nyata hasilnya, serta dengan susunan

\footnotetext{
43. Ibid, ayat 30-31

${ }^{44}$. Diantara ayat-ayat al-Qur'an yang mengangkat tema akidah dengan model dialog adalah ayat 21-24 dari surat al-Baqarah.
} 
bahasa yang fașāhah yang tidak harus memeras otak dan banyak penelitian untuk dipahami. ${ }^{45}$

Al-Qur'an tidak menggunakan metode yang ditempuh ahli kalam yang memerlukan adanya muqaddimah (premis) dan natïjah (konklusi) dalam berargumen, seperti dengan cara berargumen menggunakan sesuatu yang bersifat kulli (universal) atas yang juz' $\bar{i}$ (parsial) dalam qiyās shumul, berargumen dengan salah satu dua juz'i atas yang lain dalam qiyās tamthìl, berargumen dengan juz'î atas kulli dalam qiyās istiqrä, ${ }^{-46}$ Argumen-argumen yang disampaikan al-Qur'an dalam perdebatannya adalah dalil-dalil qat' $\bar{i}$ (pasti) yang tidak ada keraguan di dalamnya ${ }^{47}$.

Dalam penyampaian argumen-argumennya, al-Qur'an menggunakan beberapa metode di antaranya: pertama, menggunaan kata tanya penetapan (istifham taqrîî̉). Maksud dari kata Tanya ini adalah menjadikan lawan bicara mengakui dan menyatakan dengan pasti akan adanya sesuatu atau tidak adanya sesuatu tersebut. ${ }^{48}$

Di antara contoh-contoh istifham taqrïr $\bar{i}$ dalam al-Qur'an, firman Allah tentang kuasanya Allah sebagai Tuhan yang menciptakan langit dan bumi itu kuasa menciptakan kembali jasad-jasad mereka yang sudah hancur itu. Dalam firmannya ini, Allah menggunakan kata tanya penetapan (istifham taqrîîi) yaitu "Dan tidakkah Tuhan yang menciptakan langit dan bumi itu berkuasa menciptakan kembali jasad-jasad mereka yang sudah hancur itu? Benar (Dia berkuasa). Dan Dialah Maha pencipta lagi Maha Mengetahui. "\#9 Kata tanya ini bertujuan untuk membungkam orang-orang yang tidak mempercayai adanya hari kebangkitan.

Dalam ayat ini Allah mengingatkan tentang besarnya kekuasaan-Nya untuk menciptakan tujuh langit beserta isinya dan tujuh lapis bumi beserta isinya juga, sangat mampu mengembalikan jasad-jasad yang telah hancur, karena penciptaan langit dan bumi lebih besar dari dari penciptaan manusia. $^{50}$

Kedua, Analogi Asosiasi (qiyās al-tamthīi).Yang dimaksud dengan qiyās al-tamthỉl adalah penyamaan sesuatu dengan sesuatu yang lain. Proses

45. Mannā' bin Khalì al-Qatțān, Mabahith fì Ulūm al-Qur'ān, t.tp, Maktabah alMa'ārif, 2000 M./1421 H., 310

${ }^{46}$. Ibid, 310

${ }^{47}$. Alì Muhammad Șāleh Abdullah, al-Hiwār al-Dīnī al-Ibrāhimī fỉ mìzān al-Qur'ān, 180.

48 . Ibid, hal. 180

49. Al-Qur'an surat Yàsin ayat 81

${ }^{50}$. Ahmad bin Mustāâāa al-Marāghì, Tafsìir al-Marāghī, t. tp: Shirkah Maktabah wa Mathba'ah Musțāfā al-Bāb al-Halabī, 1946 M- 1365 H., 445. 
penyamaan itu dilakuakan dengan menyamakan sesuatu dengan sesuatu yang lain yang sama-sama diakui oleh lawan bicara. ${ }^{51} \mathrm{Di}$ antara contoh penggunaan qiyās al-tamthīl dalam al-Qur'an adalah firman Allah: "Sesungguhnya perumpamaan (penciptaan) 'Isa di sisi Allah, adalah seperti (penciptaan) Adam. Allah menciptakan Adam dari debu, kemudian Allah berfirman kepadanya: Jadilah (seorang manusia), maka jadilah dia. ${ }^{52}$

Dalam ayat ini Allah menjelaskan kesamaan penciptaan Nabi Isa as. dengan Nabi Adam as. yang sama-sama diciptakan tanpa seorang bapak, bahkan Nabi Adam as. bukan hanya tanpa seorang bapak tetapi juga tanpa seorang ibu. Kenyataan bahwa Adam diciptakan tanpa seorang bapak dan ibu diakui oleh semua pihak termasuk pihak orang-orang Nasrani. Hasil dari penyamaan penciptaan ini adalah bahwa penciptaan Nabi Isa tidak lebih aneh dari penciptaan Adam, sehingga apabila dikatakan Isa layak mendapat gelar sebagai anak Tuhan karena dilahirkan tanpa seorang bapak, maka Adam jauh lebih pantas dan labih layak untuk dikatakan sebagai anak Tuhan. Tetapi dalam sejarah tidak pernah ada aliran keagamaan yang meyakini Adam sebagai anak Tuhan. Semua aliran keagamaan mufakat bahwa Adam hanya manusia biasa yang mendapatkan wahyu, sehingga otomatis pengakuan orang-orang Nasrani yang meyakini Isa sebagai anak Tuhan jauh lebih tidak layak. ${ }^{53}$ Teori qiyās tamthỉl ini banyak digunakan oleh al-Qur'an dalam penetapan adanya hari kebangkitan dari kubur.

Ketiga, teori penukaran dalil (al-Intiqāl). Yang dimaksud dengan teori ini adalah penukaran dalil dengan dalil lain yang sepadan atau dari satu contoh ke contoh yang lain, dikarenakan lawan bicara tidak paham dengan dalil atau contoh yang pertama, atau ia hanya berpura-pura tidak paham dengan maksud membuat pengkaburan atau memutarbalikkan fakta. ${ }^{54}$

Ketangguhan Teori penukaran dalil ini telah dibuktikan Nabi Ibrahim ketika menghadapi ketidakpahaman yang dibuat-buat oleh raja yang mendebatinya. Kisah perdebatannya telah diabadikan oleh Allah dalam alQur'an surah al-Baqarah ayat 258.

${ }^{51}$. Ali Muhammad Șāeh Abdullah, al-Hiwār al-Dīnī al-Ibrāhimī fỉ mīzān al-Qur'ān, 199.

52. Al-Qur'an surat Āli Imrān ayat 59

53. Ibnu Kathìr al-Damashqi, Tafsirir Ibnu Kathīr, juz 2 tahqīq Samì bin Muhammad Salamah, t.tp: Dār al-Ṭibah, 1999 M.-1420 H., 57.

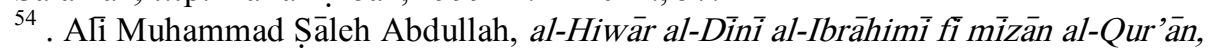
197. 
Etika Berdialog Dan Metodologi Debat dalam Al-Qur'an

\section{Epilog}

Debat dalam al-Qur'an bukanlah hanya sekedar perbantahan sengit yang menyia-nyiakan waktu dan jauh dari tujuan-tujuan positif, akan tetapidebat merupakan salah metodologi dakwah untuk mendapatkan hasil positif dari perbantahan argumenasi yang disampaikan oleh masing-masing pihak yang berbeda pendapat.Akan tetapi, hasil positif yang dicari dalam perdebatan akan menjadi nihil apabila perdebatan tersebut tidak didasari tujuan-tujuan baik.

Untuk menghindari hasil-hasil yang tidak baik dalam perdebatan, maka al-Qur'an mengajarkan etika-etika khusus dalam berdialog dan metode debat qur'anni dalam upaya mencari hasil yang positif dari setiap dialog dan perdebatan yang terjadi. Dalam prakteknya al-Qur'an banyak menggunakan dalil dan bukti-bukti kuat dan jelas yang dapat dimengerti masyarakat awam dan kaum intelek. Ungkapan-ungkapan dialognya menggunakan susunan bahasa yang fașāhah yang tidak harus memeras otak dan banyak penelitian untuk dipahami

\section{Daftar Pustaka}

Al-Qur'an

Ashūr, Muhammad al-Tāhir bin, al-Tahrīr wa al-Tanwir, juz 12, Tunis: alDār al-Tünisiyah li al-Nashr, $1984 \mathrm{M}$.

Ali Muhammad Șāleh Abdullah, al-Hiwār al-Dīnī al-Ibrāhimī fí mīzān alQur'ān, Kairo: Dār al-Salām, t.th.

Bukhārì (al), Muhammad bin Isma'ìl, Șahīh al-Bukhārī, juz 5 ditahqiq Musțafā Diyāb al-Biwāa, Bairūt: Dār Ibnu Kathīr, 1987.

Damashqì (al), Abdurrahmān bin Hasan, al-Haḍārah al-Islāmiyah Asāsuhā wa Wasāiluhā, Damaskus: Dār al-Qalam, Cet I, 1418 H.

Kathï, Ibn, Tafsir Ibnu Kathïr, juz 2 tahqìq Sami bin Muhammad Salamah, t.tp: Dār al-Ṭibah, 1999 M.-1420 H.

Manzūur, Ibn, Lisān al-'Arab, juz 2, Kairo: Dār al-Hadith, 2003.

Mahmūd, Manì' Abd. Halim dan Mohammad Amīn Abū Bakar Muawwad, Fath al-rahmān fî̀ Ulüm al-Qur'ān.

Marāghī (al), Ahmad bin Mustafā, Tafsìir al-Marāghī, t. tp: Shirkah Maktabah wa Mathba'ah Musțafā al-Bāb al-Halabī, 1946 M- 1365 $\mathrm{H}$.

Murād, Barakat Muhammad, Manhāj al-Jadal wa adab al-Hiwār fî al-Fikr alIslämi.

Musayyar, Muhammad Sayyid, al-Ilāhiyat fî al-Aqīdah al-Islāmiyah, Kairo: Maktab al-Imān, t.th. 
Qurțūbì (al), Abū Abdillah, Al-Jāmi' li Ahkām al-Qur'ān, juz 8, Kairo: Dār al-Kutub al-Misriyah, 1964.

Qushairī (al), Muslim bin Hajjāj, Sahīh Muslim, juz 4, ditahqiq Muhammad Fu'ād Abd Bāqi, Bairūt: Dār Ihyā' al-Turāth al-'Arabī, t.th, 2012.

Qatțān (al), Mannā' bin Khalil, Mabāhith fî Ulüm al-Qur'ān, t.tp, Maktabah al-Ma'āiff, 2000 M./1421 H.

Sha'rāwì (al), Muhammad Mutawalli, Tafsìr al-Sha'rāwī, t. tp: Maṭābi' Akhbār al-Yaum, t.th.

Shīli (al), Abū Umāmah Nawwar bin, al-Aql al-Fiqhỉ Ma'ālim wa Ḍaābit, Kairo: Dār al-Salām, Cet I, 2008 M-1429 H.

Ṭantāwī, Muhammad Sayyid, al-Tafsìr al-Wasiț, juz 8, Kairo: Dār Nahḍah Mișr, t.th.

Mațābi' al-Azhar, t.th.

Adab al-Hiwār fī al-Islām,t. tp: Majma' 